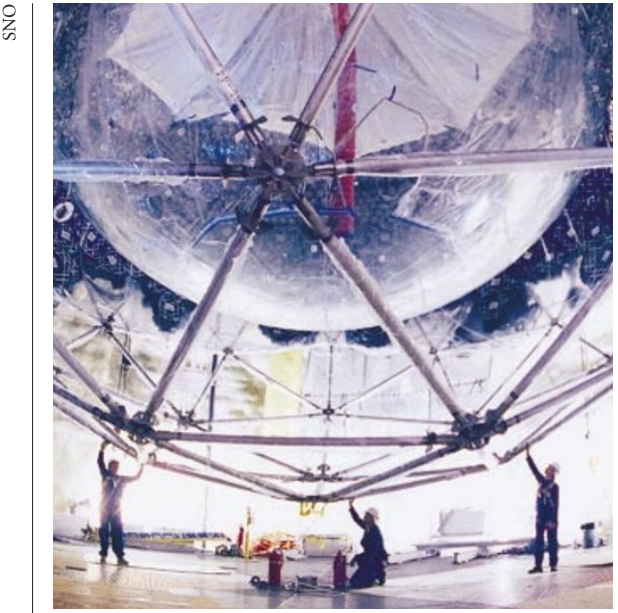

Sun spotter: heavy-water detector could provide clues to the mass density of the Universe.

\section{Scientists go down a mine to observe the Sun's neutrinos}

[MONTREAL] Scientists and government representatives from many countries gathered last week near the northern Ontario mining town of Sudbury for the opening of the Sudbury Neutrino Observatory.

The observatory, in a nickel mine $2 \mathrm{~km}$ deep, consists of 9,500 light sensors surrounding a 12-metre diameter acrylic flask that will hold 1,000 tonnes of heavy water. The heavy water comes from Atomic Energy of Canada, which had a surplus of the expensive material as a result of a decline in sales of the CANDU reactor in the 1980s.

Interactions between neutrinos and the deuterium in the heavy water will produce light flashes. The observatory's detector will make an independent measurement of all three types of neutrinos (electron, tau and muon), so should be able to determine whether neutrinos produced inside the Sun change type as they travel outwards. If they do, they must have mass, and may make a substantial contribution to the Universe's total mass density.

DavidSpurgeon

\title{
Bid to give legal protection to laboratory mice in US
}

[WASHINGTON] The US government is facing a renewed call to extend legal protection to some 20 million laboratory mice and rats not covered by current law.

The Animal Welfare Act, which is administered by the US Department of Agriculture (USDA), covers animals such as dogs, cats, rabbits, guinea pigs and non-human primates but, under an exemption approved in 1976 , does not apply to mice, rats and birds.

Mice and rats are estimated to make up at least 85 per cent of US research animals. "These animals deserve the same protection as others used in experiments," said Tina Nelson, the executive director of the American Anti-Vivisection Society (AAVS). The society, a sharp critic of the treatment of laboratory animals, announced last week that it was petitioning the USDA. The move follows a previous unsuccessful attempt by other groups in 1989. "These animals are not afforded even minimal coverage by the Act," said Nelson.

Nelson argues that this has removed incentives for scientists to seek alternatives. She points, for example, to the "ascites method" used to produce monoclonal antibodies, in which tumours are grown in the abdomens of mice and the antibodies generated are tapped by syringe.

The act allows for unannounced laboratory inspections by USDA, and requires researchers to report annually on the numbers of laboratory animals in their care. Also, institutional committees that review experimental protocols must require investigators to consider non-animal alternatives.

The USDA has 180 days to respond to the petition. If it denies it, Nelson says, the AAVS will sue the government. The 1989 petition, which was similar to the current one, was denied by USDA. The petitioners sued, but a court found that they had not demonstrated sufficient legal standing or injury to the rodents to justify the suit. The AAVS says its petition addresses those weaknesses.

Scientific groups, although not opposing the extension of the law in principle, say that the success of the petition could cripple the resource-starved USDA inspectorate, particularly as it would have to inspect small institutions such as community colleges and even high schools that use only rodents in their laboratories. "It would destroy USDA's already limited ability to meet its inspection mandates," says Tony Mazzaschi, a research policy analyst at the Association of American Medical Colleges.

Ralph Dell, director of the Institute for Laboratory Animal Research - a division of the National Research Council - estimates that the increased workload would require a doubling of USDA's $\$ 9.2$ million budget for enforcing the act.

Others argue that rodents are already cared for scrupulously. "The personnel at research facilities don't need a federal law in order to be motivated to care for their animals well. Good science demands it," says Barbara Rich, executive vice-president of the National Association for Biomedical Research.

The scientists also claim that extension of the law would make little difference to the vast majority of rodent-using institutions, which are already governed by other federal policies that cover rodent use.

For instance, scientists funded by the Public Health Service - including all those on National Institutes of Health grants - are covered by a policy on the humane use of 1 aboratory animals that applies to all vertebrates. This policy does not, however, have the force of law, and it requires neither reporting of numbers nor surprise laboratory inspections.

MeredithWadman

\section{Space researchers were not spying, says India's Supreme Court}

[NEW DELHI] India's Supreme Court exonerated two leading space scientists and four others last week in the culmination of a spy case that rocked the country four years ago (see Nature 372, 491; 1994). The two scientists worked for the Indian Space Research Organization (ISRO).

The court also criticized the government of the state of Kerala for trying to reopen the investigation after it had been closed by a central government agency. The court ordered the state to pay $\$ 2,500$ in compensation to each of the six accused.

Nambi Narayanan and S. Chandrasekar were scientists at ISRO's liquid propulsion centre in Thiruvandapuram when they were arrested by Kerala police and charged with passing information about the development of India's cryogenic rocket engine.

Also arrested were two women from the Maldives, and two Indian businessmen who had links with a Russian aerospace company. All were accused of being part of a spy ring financed by a third country.

The charges were based on the fact that addresses and contact numbers of ISRO scientists and of the businessmen were found in the hands of the Maldivian women, one of whom worked for the islands' intelligence agency.

India's Central Bureau of Investigations, which took over the case, found no evidence of espionage and declared the case closed in April 1996. But the Kerala government disagreed and sought a new investigation by the state police.

Although it is not officially admitted, it is believed that low morale at ISRO caused by the investigation into the spying allegations has helped push India's geostationary launch-vehicle programme back by two years.

K.S. Jayaraman 